\title{
Analisis Bibliometrik untuk Memetakan Tren Penelitian Covid-19 dalam Topik Ilmu Komputer
}

\author{
Bibliometric Analysis to Mapping Covid-19 Research Trends in Computer Science
} Topics

\author{
Tri Wahyu Widyaningsih ${ }^{1}$, Meta Amalya Dewi ${ }^{2}$, Andrianingsih ${ }^{3}$ \\ ${ }^{1}$ Informatic Engineering, Tanri Abeng University \\ ${ }^{2}$ Information System, Tanri Abeng University \\ ${ }^{3}$ Information System, Universitas Nasional \\ E-mail: ${ }^{1}$ tri.widyaningsih@tau.ac.id, ${ }^{2}$ meta.amalya@tau.ac.id, ${ }^{3}$ andrianingsih@civitas.unas.ac.id
}

\begin{abstract}
Abstrak
Covid-19 berdampak pada seluruh penduduk di dunia, pandemi ini tidak hanya mempengaruhi sektor kesehatan, namun juga ekonomi, pendidikan, transportasi, industri, dan pemerintahan. Covid-19 hadir sebagai topik menarik bagi para peneliti, hal tersebut nampak pada data yang diperoleh dari Scopus, Crossref, IEEEXplore, dan Google Scholar yang di dalamnya memuat penelitian di bidang ilmu komputer yang membahas covid-19, dengan berbagai tujuan penelitian untuk memperoleh inovasi maupun solusi dari permasalahan yang timbul akibat pandemi. Penelitian ini dilakukan untuk memperoleh topik apa saja yang paling diminati oleh para peneliti terkait dengan covid 19, dan menganalisis serta membandingkan relasi antara topik Artificial Intelligence, Data Mining, Deep Learning, Machine Learning, dan Internet of Thing dari sumber google scholar, scopus, IEEEXplore, dan crossref dengan menggunakan analisis bibliometrik. Metode occurrence dan link strength digunakan untuk memvisualisasikan jejaring berdasarkan kata kunci dari ke lima topik bidang ilmu komputer serta hubungan antara lima topik tersebut dengan topik riset lainnya. Hasil analisis bibliometric menunjukkan peringkat dari ke empat penyedia sumber data artikel di lihat dari persentase setiap topik penelitian adalah sebagai berikut : Scopus, Crossref, IEEEXplore, dan Google Scholar. Analisis link strength dan occurence terhadap kelima topik penelitian menunjukkan peringkat yang dapat dilihat dari banyaknya link strength dan occurrence di setiap penyedia sumber artikel, dengan hasil peringkat sebagai berikut : Deep Learning, Artificial Intelligence, Internet of Things, Machine Learning, dan Data Mining.
\end{abstract}

Kata kunci: Bibliometrik, Covid-19, Occurrence, Link Strength, Ilmu Komputer

\begin{abstract}
Covid-19 affects all population in the world, this pandemic not only affects the health sector, but also the economy, education, transportation, industry and government. Covid-19 is a very interesting topic for researchers, this can be seen in the data obtained from Scopus, Crossref, IEEEXplore, and Google Scholar which includes research in the field of computer science that discusses covid-19, with various research objectives for obtain innovations and solutions to problems arising from the pandemic. This research was conducted to find out what topics the researchers are most interested in related to Covid 19, analyze and compare the relationships between the topics of Artificial Intelligence, Data Mining, Deep Learning, Machine Learning, and the Internet of Thing from Google Scholar, Scopus, IEEEXplore, and crossref using bibliometric analysis. Occurrence and link strength methods are used to visualize the network based on keywords from the five topics in computer science and visualize the relationship between these five topics and other research fields. The results of the bibliometric analysis show that Scopus has a balanced percentage of links strengt from the five topics, followed by Google Scholar, IEEEXplore and finally Crossref has an unbalanced percentage result.
\end{abstract}

Keywords: Bibliometrics, Covid-19, Link Strength, Computer Science 


\section{PENDAHULUAN}

Pada akhir 2019 kasus pneumonia jenis baru muncul di Wuhan, China [1] dan kurang dari 30 hari kalender, penyakit ini menyebar secara cepat ke berbagai wilayah China bahkan menyebar ke Thailand, Jepang dan Korea Selatan [2] yang kemudian bulan Februari 2020 tepat di tanggal 11 nama penyakit ini diumumkan oleh WHO sebagai Coronavirus Disease (COVID19) [3]. Pandemi Covid-19 ini menjadi perhatian dunia karena penyebarannya yang tak terkendali menyebabkan lonjakan penambahan kasus [4]. Data sebaran di 223 negara dan wilayah yang diambil dari website WHO pada tanggal 28 Februari 2021 menunjukkan jumlah terkonfirmasi mencapai 100.455.529 kasus dan angka kematian berjumlah 2.166.440 [5]. Dari awal kemunculannya hingga data diambil, menggambarkan angka statistik yang kian meninggi dengan kenaikan fluktuatif per hari [6] dan belum ada tanda-tanda penurunan, hal ini menjadi perhatian banyak pihak, salah satunya adalah para peneliti [7], yang membahas dan mempublikasikan kajian penelitiannya, untuk di jadikan referensi atau pun studi literature dalam menemukan penyebab, perkembangan, dan upaya menemukan solusi penyembuhan serta antisipasi meminimalisir penyebarannya.

Penelitian ini dilakukan dengan analisis bibliometrik terhadap publikasi ilmiah yang menjadi tools bermanfaat untuk mengetahui proses generasi dan perkembangan pengetahuan, serta untuk mengevaluasi kualitas bidang ilmu dan dampak yang dibawanya dalam wilayah akademis [8]. Selain itu, analisis bibliometrik bisa dimanfaatkan untuk mengetahui pemetaan riset dari penelitian yang sedang dilakukan, sudah dilakukan serta peluang di masa yang akan datang [9].

Tujuan penelitian ini untuk mengetahui pemetaan riset penelitian ke dalam beberapa ruang lingkup bidang teknologi dengan membahas beberapa parameter topik mengenai Artificial intelligence, Deep Learning, Machine Learning, Data Mining dan Internet of Things yang terpublikasi selama masa pandemi berlangsung. Proses pemetaan riset dilakukan dengan tahapan proses seleksi obyek, menghitung obyek yang berinteraksi, proses normalisasi, membuat peta dan menampilkan peta lalu mengevaluasi peta [10]. Vosviewer digunakan untuk menampilkan visualisasi peta bibliometrik yang diunduh dari laman: www.vosviewer.com. Tampilan peta bibliometrik divisualisasikan dengan vosviewer berdasarkan nama penulis atau jurnal dengan data co-citation, atau berdasarkan kata kunci dengan data co-occurrence dengan bentuk tampilan peta label, sketsa dan density, serta klaster [11] Klaster dalam peta dari vosviewer disajikan dengan perbedaan warna. Setiap parameter dioperasikan oleh algoritma klaster yang dapat diubah agar dapat dihasilkan klaster yang lebih banyak atau lebih sedikit [12].

\section{METODE PENELITIAN}

\subsection{Pengumpulan data}

Data dikumpulkan dari empat sumber penyedia artikel yaitu Scopus, Google Scolar, IEEEXplore, dan Crossref. Artikel yang akan dianalisis dibatasi untuk publikasi tahun 2000, dari bulan Januari hingga Desember. Kata kunci yang digunakan adalah covid-19 dan kelima topik penelitian yaitu Artificial intelligence, Deep Learning, Machine Learning, Data Mining dan Internet of Things.

IEEEXplore menyediakan tautan khusus bagi para pengguna untuk melihat dan mengakses data artikel terkait pandemi covid-19 dari berbagai bidang keilmuan, hal ini sangat membantu proses pengumpulan data, karena pengguna dapat menentukan bidang keilmuan dengan topik sesuai dengan minat penelitian. Sementara artikel pada Scopus, Google Scolar dan Crossref diakses menggunakan Application Programming Interface (API), yang dapat diperoleh apabila telah memiliki akun pada laman Scopus. Aplikasi pendukung yang digunakan sebagai antar muka dalam pengaksesan data adalah Publish or Perish 7, adapun jumlah perolehan data artikel dapat dilihat pada tabel 1 . 
Tabel 1 Data Artikel Penelitian

\begin{tabular}{|c|l|c|}
\hline No & \multicolumn{1}{|c|}{ Sumber Data } & Jumlah Data \\
\hline 1 & Scopus & 525 \\
\hline 2 & Crossref & 1000 \\
\hline 3 & Google Scholar & 213 \\
\hline 4 & IEEEXplore & 1253 \\
\hline
\end{tabular}

Berdasarkan tabel data di atas diperoleh total artikel sebanyak 2991 dengan kata kunci covid-19 dan kelima topik penelitian yang telah ditentukan dengan hasil persentase IEEEXplore adalah $1253(41.89 \%)$ artikel yang diakses secara langsung, sementara Scopus diperoleh 525 (17.55\%), Crossref 1000 (33.43\%) dan Google Scholar 213 (7.12\%). Jumlah artikel dari setiap topik pada masing-masing sumber data tercantum pada table 2 berikut:

Tabel 2 Jumlah Artikel / Topik

\begin{tabular}{|c|c|c|c|c|c|}
\hline $\begin{array}{c}\text { Sumber Data / } \\
\text { Topik Penelitian }\end{array}$ & $\begin{array}{c}\text { Artificial } \\
\text { Intelligence }\end{array}$ & $\begin{array}{c}\text { Deep } \\
\text { Learning }\end{array}$ & $\begin{array}{c}\text { Machine } \\
\text { Learning }\end{array}$ & $\begin{array}{c}\text { Data } \\
\text { Mining }\end{array}$ & IoT \\
\hline Scopus & 132 & 164 & 164 & 25 & 40 \\
\hline Google Scholar & 44 & 88 & 74 & 3 & 4 \\
\hline IEEEXplore & 300 & 253 & 300 & 200 & 200 \\
\hline Crossref & 200 & 200 & 200 & 200 & 200 \\
\hline
\end{tabular}

\subsection{Bibliometrik}

Bibliometrik merupakan bidang keilmuan mengenai analisi kuantitatif terhadap buku, artikel, dan jenis komunikasi tertulis lainnya [13]. Pemetaan bibliometrik merupakan cara yang efektif untuk digunakan sebagai metode visualisasi yang menunjukkan sekumpulan data yang bermanfaat [13].

Link merupakan koneksi atau hubungan antara dua item, seperti hubungan antara publikasi (bibliographic coupling link), penulis atau peneliti (co-authorship), maupun hubungan antara istilah (co-occurrence) [14]. Masing-masing hubungan tersebut memiliki sebuah kekuatan (strength) yang ditunjukkan dengan sebuah nilai bilangan positif, semakin tinggi nilai menunjukkan hubungan yang semakin kuat, yang di dalam vosviewer disebut dengan pembobotan links atau total link strength. Co-occurrence menunjukkan hubungan antara dua item (artikel) berdasarkan keyword atau istilah [14].

Metode yang digunakan pada analisis bibliometrik ini adalah pembobotan menggunakan link dan occurrence, yang menganalisis hubungan antara keyword dan istilah antara artikel, keyword dan istilah yang digunakan adalah covid-19, dan kelima topik penelitian pada ilmu komputer yaitu Artificial intelligence, Deep Learning, Machine Learning, Data Mining dan Internet of Things.

Meskipun aplikasi teks mining vosviewer digunakan sebagai visualisasi pemetaan hasil analisis artikel, perlu dipahami bagaimana metode co-occurrence dan link strength diperoleh dalam sebuah persamaan. Berikut ini penjabaran mengenai indeks inklusi digunakan untuk mendeteksi hierarki subjek dalam sebuah penelitian [15] dan e-coefficient yang merupakan persamaan dalam menentukan probabilitas co-occurrence dan link strength.

$$
\begin{array}{ll}
\mathrm{I}_{\mathrm{ij}}=\mathrm{C}_{\mathrm{ij}} / \min \left(\mathrm{C}_{\mathrm{i}}, \mathrm{C}_{\mathrm{j}}\right) \ldots \ldots \ldots \ldots(1) \\
\mathrm{I}_{\mathrm{ij}} \quad \text { : Indeks Inklusi } \\
\mathrm{C}_{\mathrm{ij}} \quad \text { : Jumlah dokumen dengan keyword yang sama }\left(\mathrm{M}_{\mathrm{i}}, \mathrm{M}_{\mathrm{j}}\right) \text { muncul; } \\
\mathrm{C}_{\mathrm{i}} \quad \text { : Frekuensi kemunculan keyword } \mathrm{M}_{\mathrm{i}} \text { pada sekumpulan artikel; } \\
\mathrm{C}_{\mathrm{j}} \quad \text { : Frekuensi kemunculan keyword } \mathrm{M}_{\mathrm{j}} \text { pada sekumpulan artikel } \\
\min \left(\mathrm{C}_{\mathrm{i}}, \mathrm{C}_{\mathrm{j}}\right): \text { Minimum frekuensi dari } \mathrm{C}_{\mathrm{i}} \text { dan } \mathrm{C}_{\mathrm{j}}
\end{array}
$$

Nilai $\mathrm{I}_{\mathrm{ij}}$ diantara 0 dan 1 . Ketika $\mathrm{C}_{\mathrm{i}}>\mathrm{C}_{\mathrm{j}}$ maka $\mathrm{M}_{\mathrm{i}}$ lebih umum daripada $\mathrm{M}_{\mathrm{j}}$. Kasus yang ekstrim ketika nilai $I_{i j}=1$, maka $M_{j}$ sepenuhkan disertakan dengan $M_{i}$ yaitu $M_{j}$ selalu muncul bersamaan dengan $\mathrm{M}_{\mathrm{i}}$ dalam artikel yang sama. 
Indeks lain yang digunakan untuk menghitung nilai asosiasi antara pasangan keyword (kata). Koefisien ini disebut dengan ekuivalen indeks (e-coefficient) atau disebut dengan length, yang didefinisikan dengan persamaan di bawah ini :

$$
\begin{aligned}
\mathrm{E}_{\mathrm{ij}} & =\left(\mathrm{C}_{\mathrm{ij}} / \mathrm{C}_{\mathrm{j}}\right) *\left(\mathrm{C}_{\mathrm{ij}} / \mathrm{C}_{\mathrm{i}}\right) \\
& =\left(\mathrm{C}_{\mathrm{ij}}\right)^{2} /\left(\mathrm{C}_{\mathrm{i}} * \mathrm{C}_{\mathrm{j}}\right)
\end{aligned}
$$

$\mathrm{E}_{\mathrm{ij}}$ memiliki nilai antara 0 dan $1 . \mathrm{E}_{\mathrm{ij}}$ mengukur probabilitas dari kata ${ }_{\mathrm{i}}$ yang muncul secara bersamaan dalam sekumpulan dokumen yang diindeks oleh kata ${ }_{j}$ maupun sebaliknya.

\section{HASIL DAN PEMBAHASAN}

Analisis bibliometrik ini dilakukan melalui beberapa tahapan, diantaranya adalah pengumpulan data menggunakan software Publish or Perish 7 seperti pada gambar 1, pencarian berdasarkan jenis artikel jurnal dan artikel konferensi dengan memasukkan kata kunci "covid 19" dan tahun pencarian 2020 yang datanya tersimpan dengan format txt yang dikelompokkan berdasarkan sumber penyedia artikel, kemudian data diimport ke Vosviewer satu persatu, selanjutnya digunakan pembobotan occurrence dan link strength yang dapat dilihat pada gambar 2, maka diperoleh hasil pemetaan penelitian dari keempat sumber penyedia data artikel berdasarkan lima topik penelitian di bidang ilmu komputer.

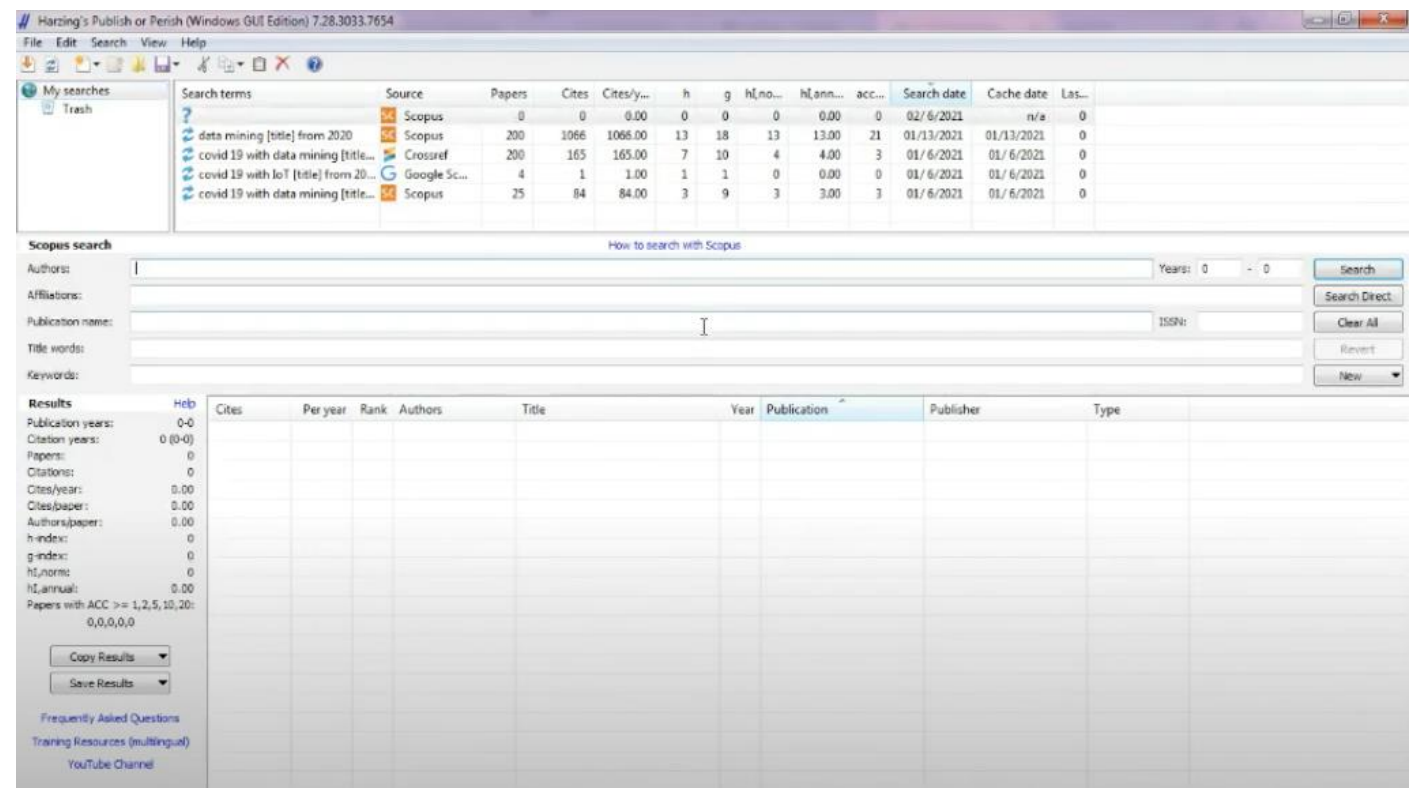

Gambar 1 Proses pengambilan data pada Publish or Perish 


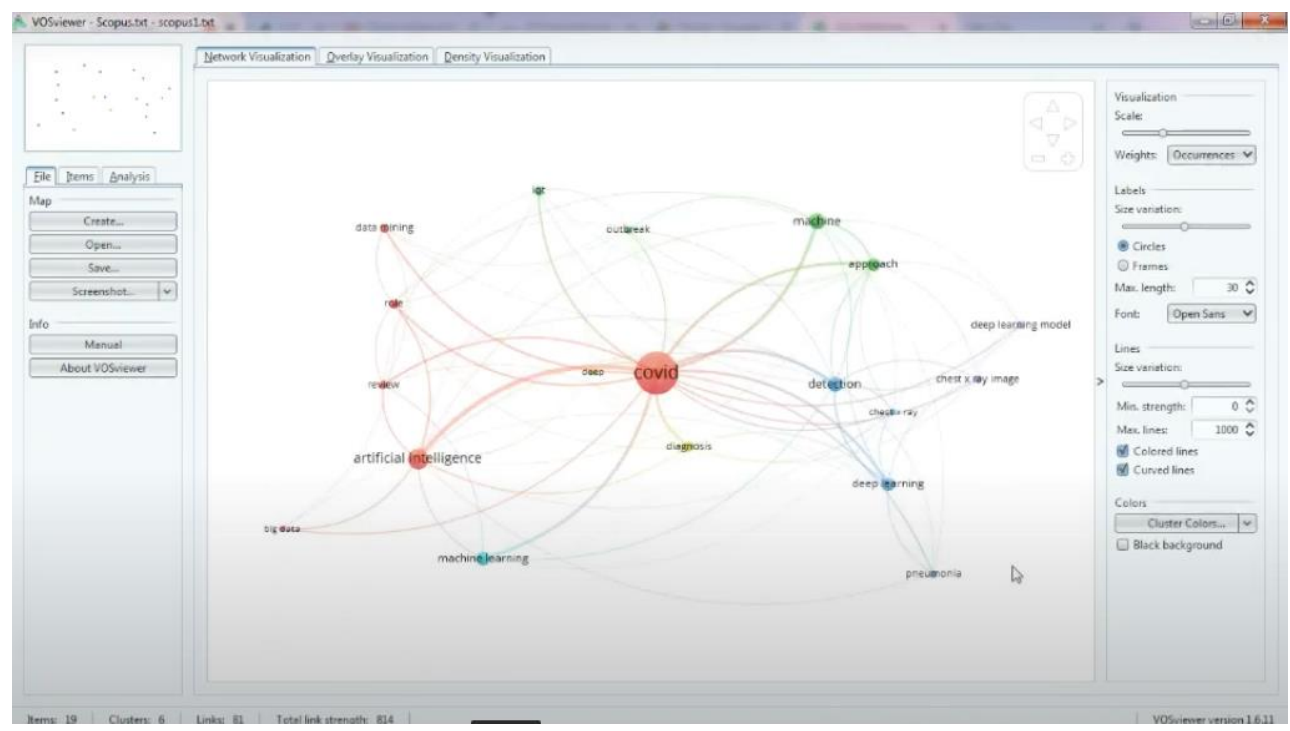

Gambar 2 Proses pembobotan data di Vosviewer

\subsection{Google Scholar}

Pada google scholar topik penelitian yang memiliki occurence dan link strength dengan pandemic covid-19 adalah Artificial Intelligence (AI) dan Deep Learning (DL). Pada gambar 3 tampak bahwa AI memiliki lebih banyak link penelitian dengan topik lain dibandingkan dengan DL.

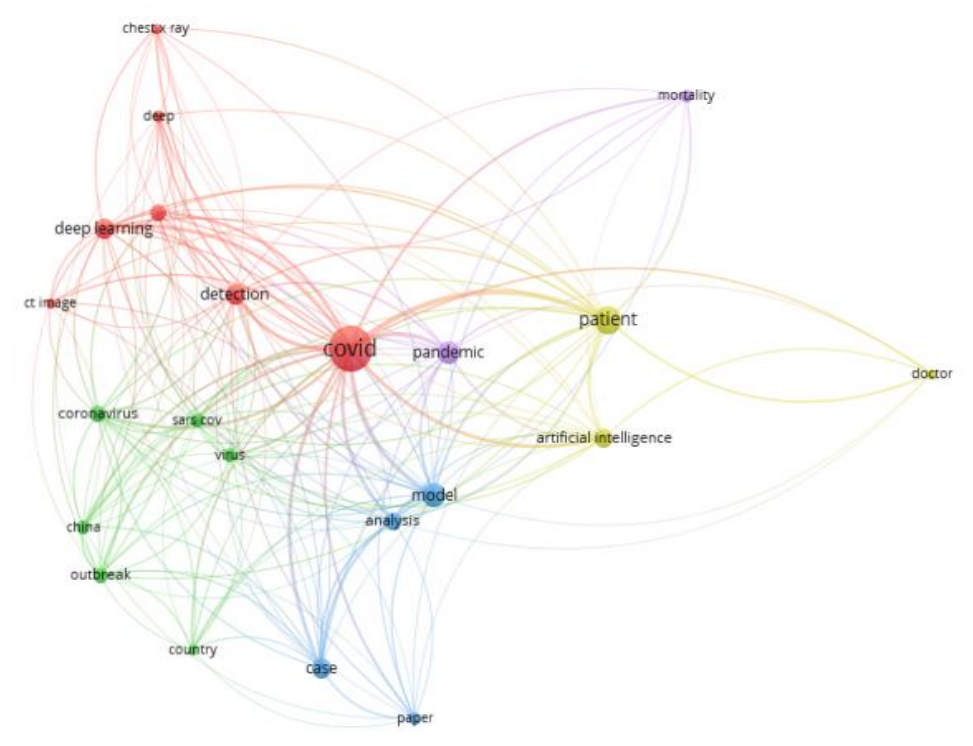

Gambar 3 Peta visualisasi penelitian pada google scholar

Agar lebih jelas, berikut ditampilkan pemetaan google scholar untuk masing-masing topik. 


\subsection{Deep Learning}

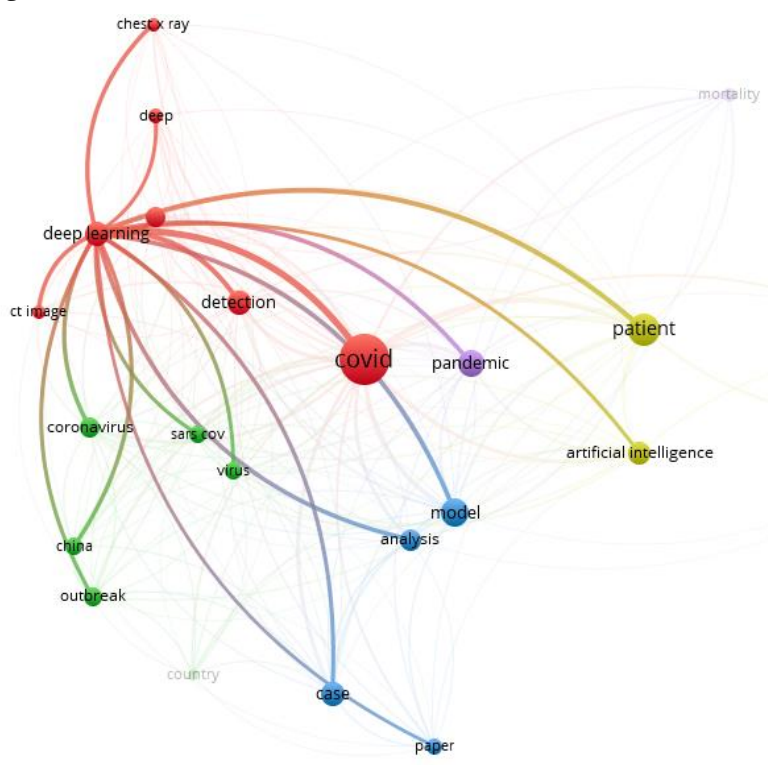

Gambar 4 Peta visualisasi topik riset Deep Learning

Pada topik Deep Learning, memiliki link riset yang hampir sama dengan Artificial Intelligence dengan 5 klaster yang berelasi erat topiknya seputar CT Image, Chese X-Ray, dan detection. Sehingga dapat disimpulkan bahwa masih ada peluang riset Deep Learning dengan mortality, doctor, dan country, serta dengan ke 4 topik lainnya

\subsection{Artificial Intelligence}

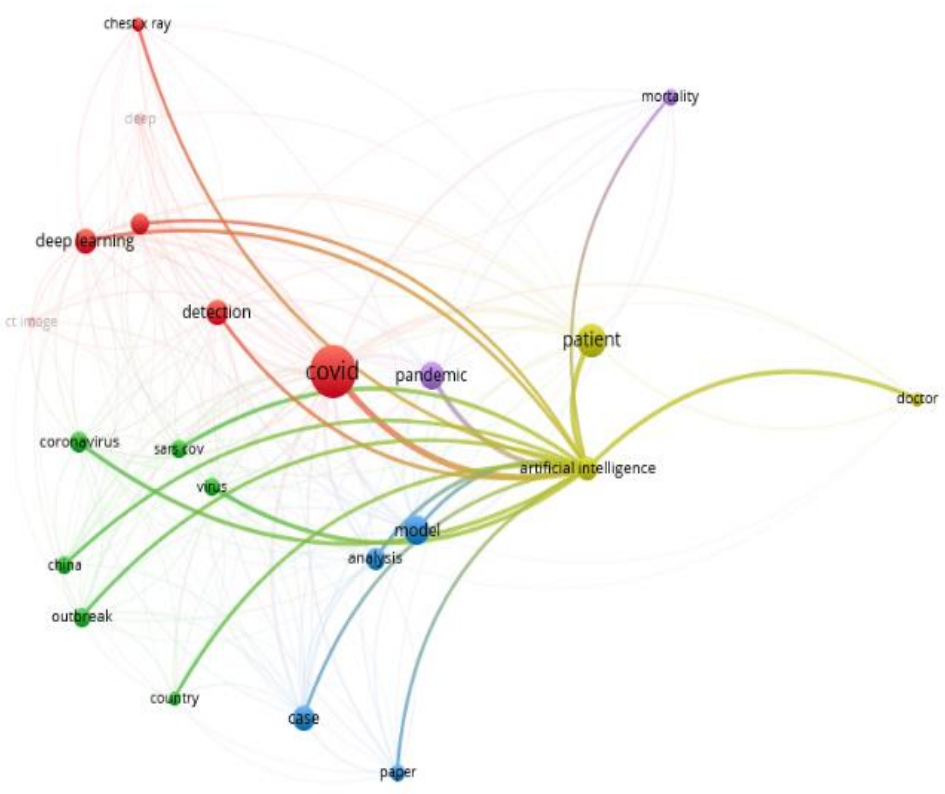

Gambar 5 Peta visualisasi topik Artificial Intelligece

Analisis Vosviewer menampilkan keterhubungan dari topik Artificial Intelligent yang menghasilkan 5 klaster berdasarkan perbedaan warna pada gambar 5 yang lebih dekat hubungannya dengan topik riset pasien, pandemik, model dan analisis. Pada pemetaan ini dapat disimpulkan bahwa belum ada link riset antara Artificial Intelligent dengan Data Mining, Machine Learning, dan Internet of Things. 


\subsection{Crossref}

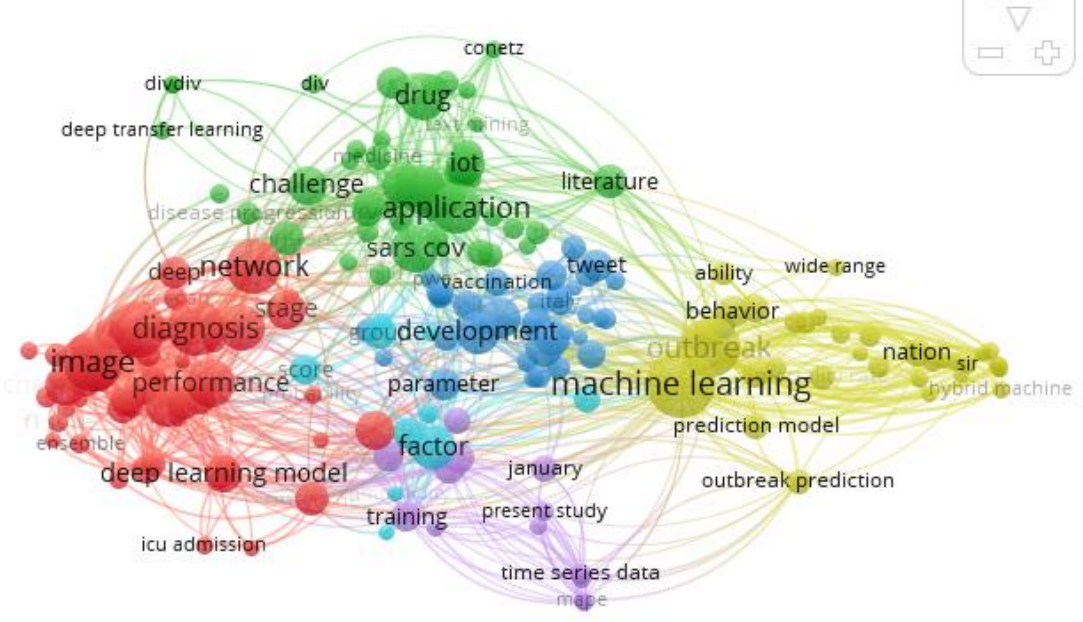

Gambar 6 Peta visualisasi penelitian pada Crossref

Vosviewer menghasilkan analisis pemetaan penelitian menjadi 6 klaster yang menampilkan tren perkembangan penelitian melalui Crossref dengan total data terakses sebanyak 1000 artikel dan memunculkan topik Machine Learning, Internet of Things dan Deep Learning. Secara detail link topik Machine Learning dan Internet of Thing juga divisualisasikan pada gambar 7, 8 dan 9 .

\subsection{Machine Learning}

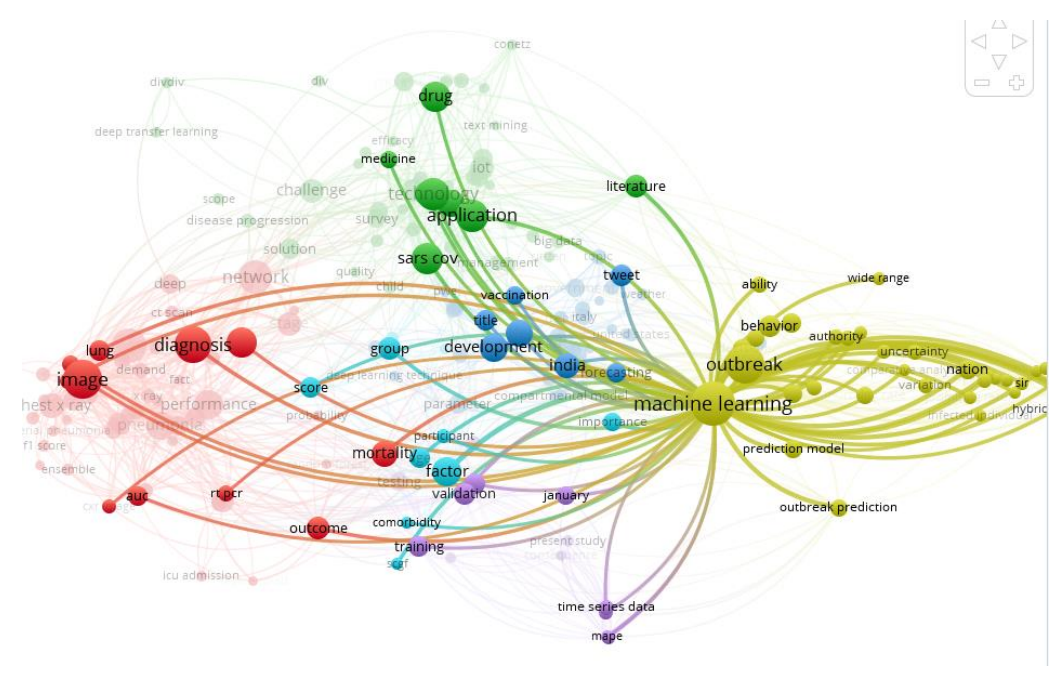

Gambar 7 Peta visualisasi topik riset Machine Learning melalui Crossref

Topik Machine Learning, memiliki kurang lebih 60 link dengan topik penelitian lainnya, dan Machine Learning termasuk topik penelitian yang memiliki link strength dominan. 


\subsection{Internet of Thing}

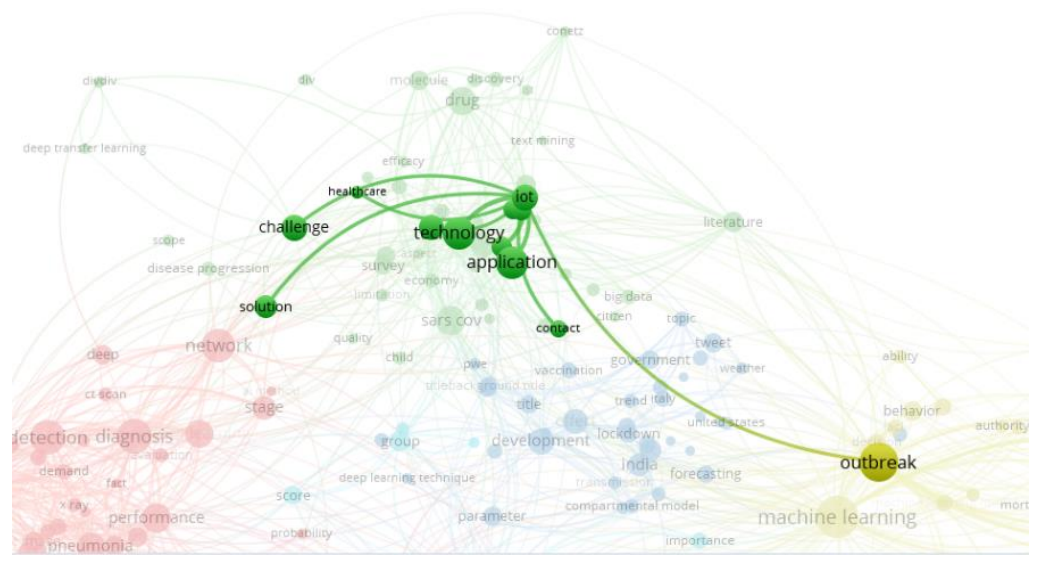

Gambar 8 Peta visualisasi topik riset IoT melalui Crossref

Topik IoT hanya memiliki 10 link dengan topik penelitian lainnya seperti outbreak, contact, application, technology, healthcare, challenge dan lainnya.

\subsection{Deep Learning}

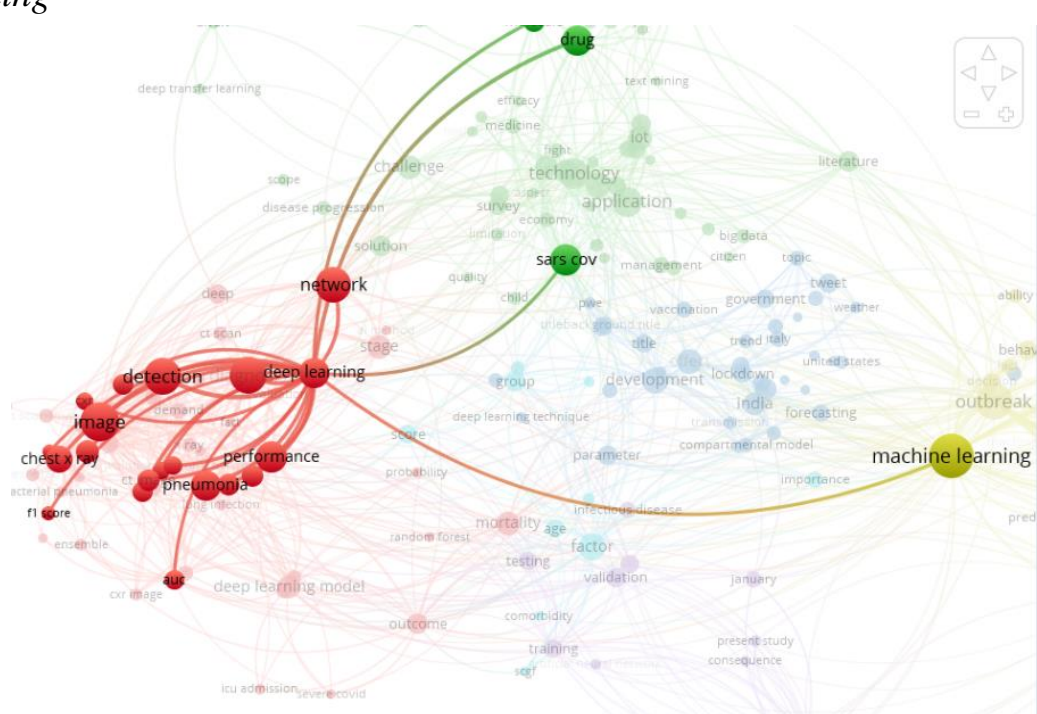

Gambar 9 Peta visualisasi topik riset Deep Learning melalui Crossref

Topik Deep Learning memiliki kurang lebih 21 link dengan topik penelitian lainnya seperti network, detection, image, chest x ray, pneumonia, performance dan yang lainnya.

\subsection{Scopus}

Hasil pemetaan artikel pada Scopus terlihat lebih merata dengan perolehan data untuk topik riset Deep Learning 164 data, sama seperti Machine Learning 164 data, Artificial Intelligent 132, Internet of Think 40, Data Mining 25, kemudian dihasilkan visualisasi pemetaan penelitian dari Vosviewer pada gambar 10. 


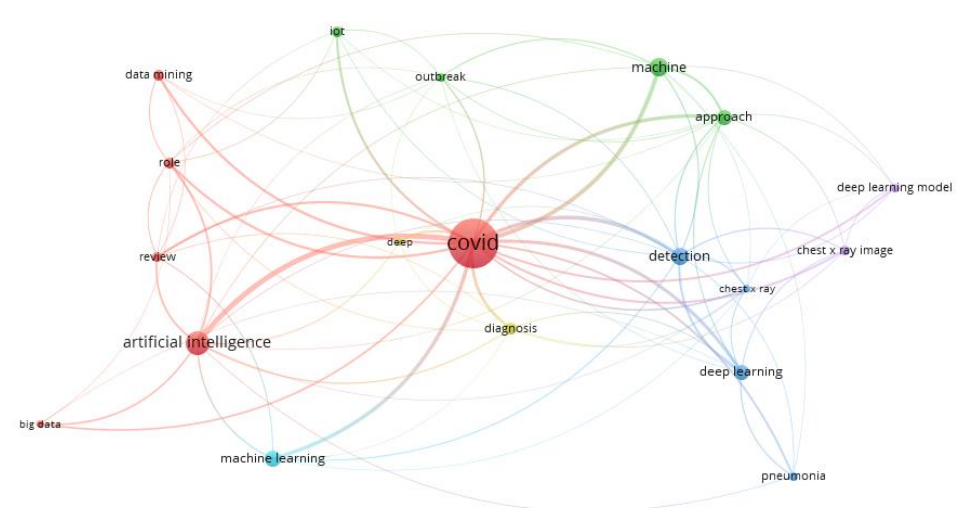

Gambar 10 Peta visualisasi penelitian pada Scopus

Pada klaster merah terdapat Data Mining dan Artificial Intelligence, Machine Learning dan Deep Learning di klaster biru, Internet of Thing di klaster hijau. Visualisasi ini juga memperlihatkan banyaknya link topik sehingga dapat disimpulkan bahwa tren penelitian teindeks Scopus masih banyak diminati untuk kelima bidang komputer tersebut.

\subsection{Deep Learning}

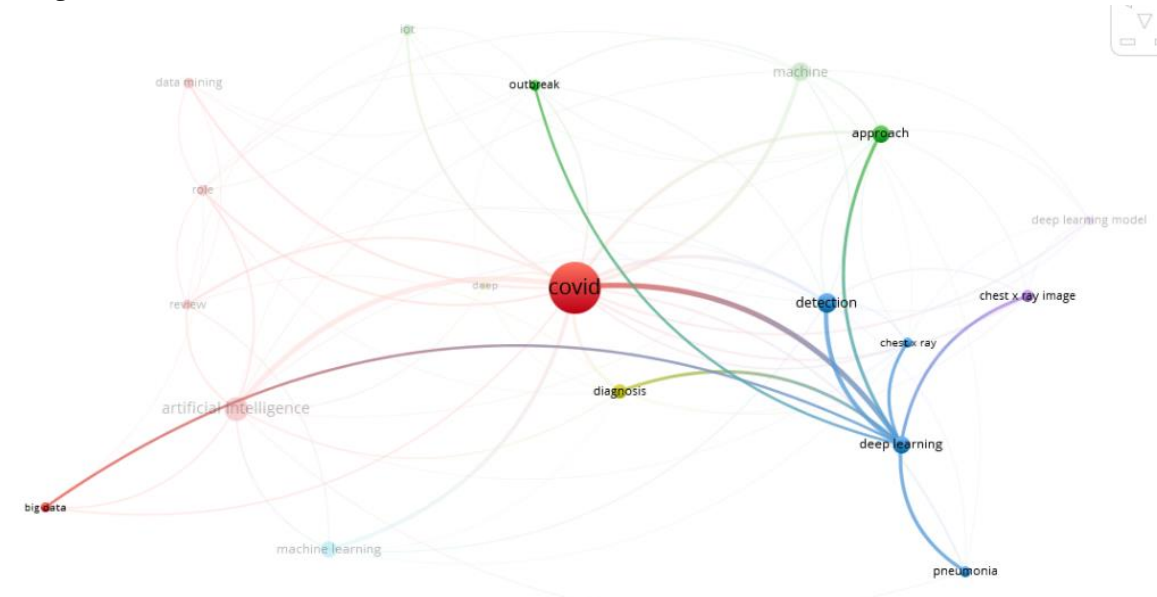

Gambar 11 Peta visualisasi link topik riset Deep Learning pada Scopus

Gambar 11 di atas memperlihatkan bahwa penelitian Deep learning memiliki link terkuat dengan topik pneumonia, chest x-ray, chest x-ray image, detection dan approach. Juga ada link topik diagnosis, outbreak dan big data. 


\subsection{Artificial Intelligence}

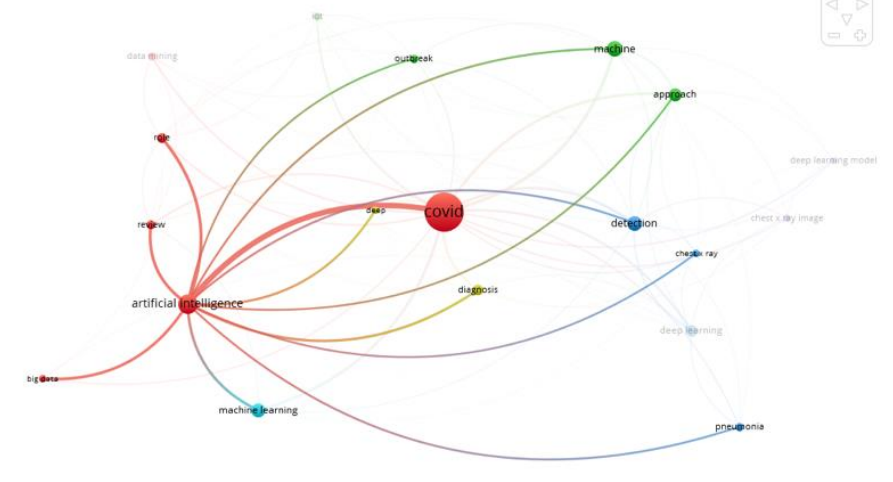

Gambar 12 Peta visualisasi link topik Artificial Intelligence pada Scopus

Penelitian topik Artificial Intelligence pada gambar 12 memiliki korelasi dengan topik riset Big Data dan Machine Learning, sementara link topik terlihat dengan review, role, outbreak, diagnosis, approach, detection, chest $\mathrm{x}$-ray dan pneumonia

\subsection{Machine Learning}

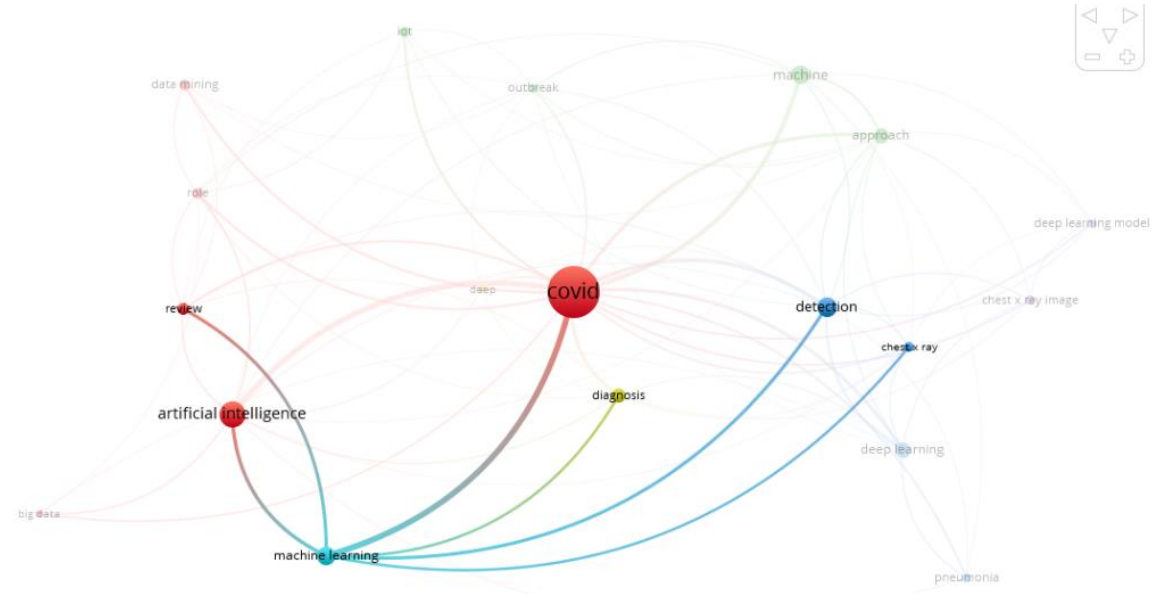

Gambar 13 Peta visualisasi link topik riset Machine Learning pada Scopus

Gambar 13 memperlihatkan link topik Machine Learning yang memiliki korelasi dengan topik Artificial Intelligence serta 4 topik lain, yaitu diagnosis, detection, chest x-ray dan review. 


\subsection{Internet of Thing}

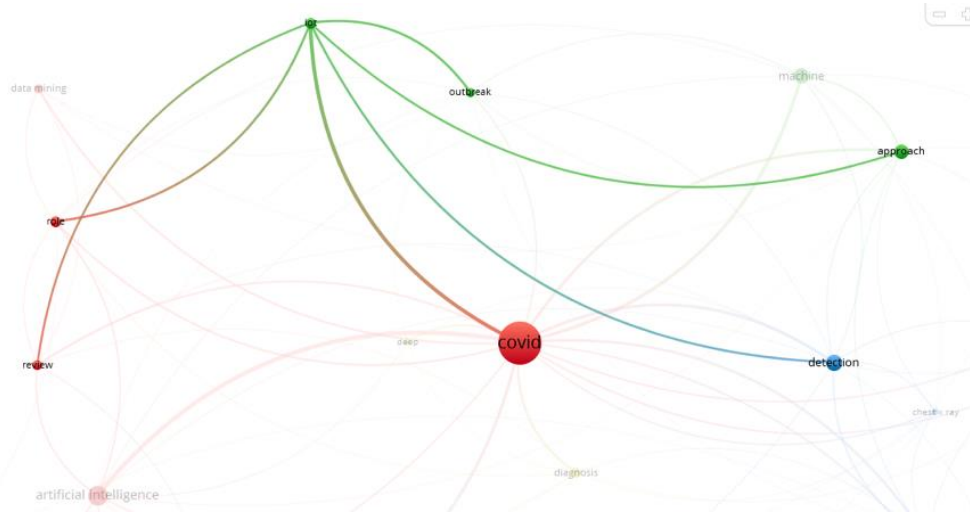

Gambar 14 Peta visualisasi link topik riset IoT pada Scopus

Pada gambar 14 tampak penelitian bidang Internet of Think yang memiliki korelasi kuat dengan topik covid, juga terhadap topik outbreak, role, review, approach dan detection.

\subsection{Data Mining}

Sementara penelitian topik Data Mining pada gambar 15 memperlihatkan link topik dengan role, review, outbreak dan approach.

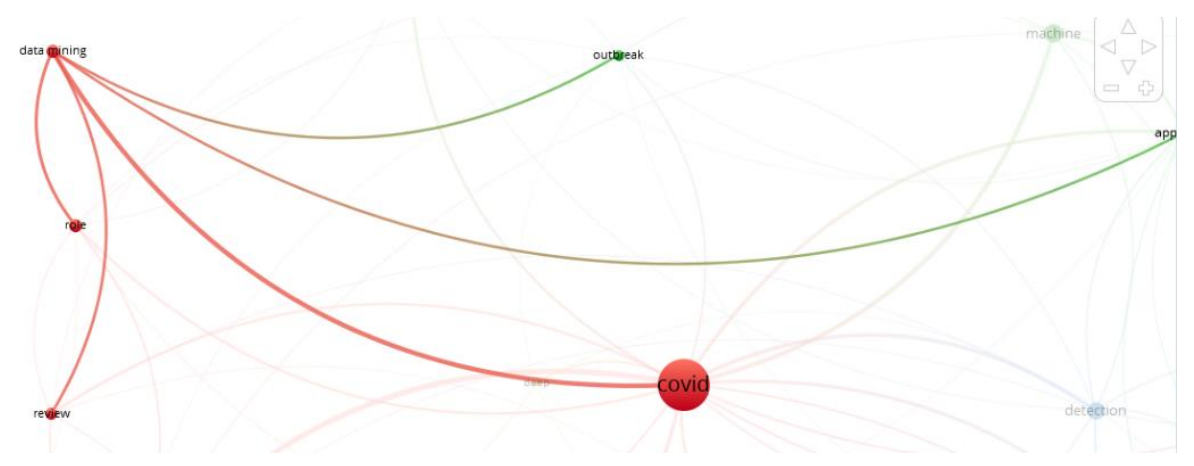

Gambar 15 Peta visualisasi link topik riset Data Mining pada Scopus 


\subsection{IEEEXplore}

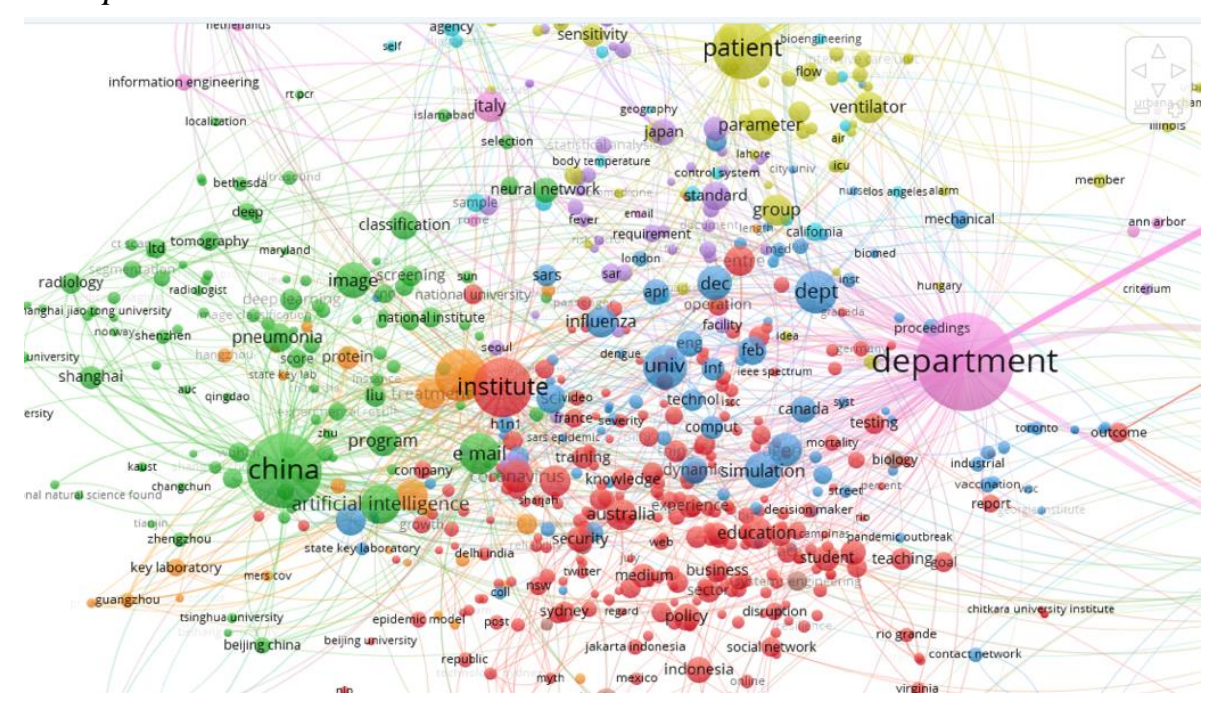

Gambar 16 Peta visualisasi penelitian pada IEEExplore

Gambar 16 di atas memperlihatkan peta penelitian melalui pencarian IEEExplore bahwa frekuensi kemunculan yang tinggi pada topik departemen, china, patient, dan ada topik Artificial Intelligence dan Deep Learning namun masih sedikit dengan bulatan yang kecil yang diperjelas melalui gambar 17 dan 18 berikut.

\subsection{Artificial Intelligence}

Gambar 17 menampilkan penelitian topik Artificial Intelligence yang memiliki link topik terdekat dengan epidemic model, republic, policy, institute, pneumonia, image juga ada topik departemen dan patient.

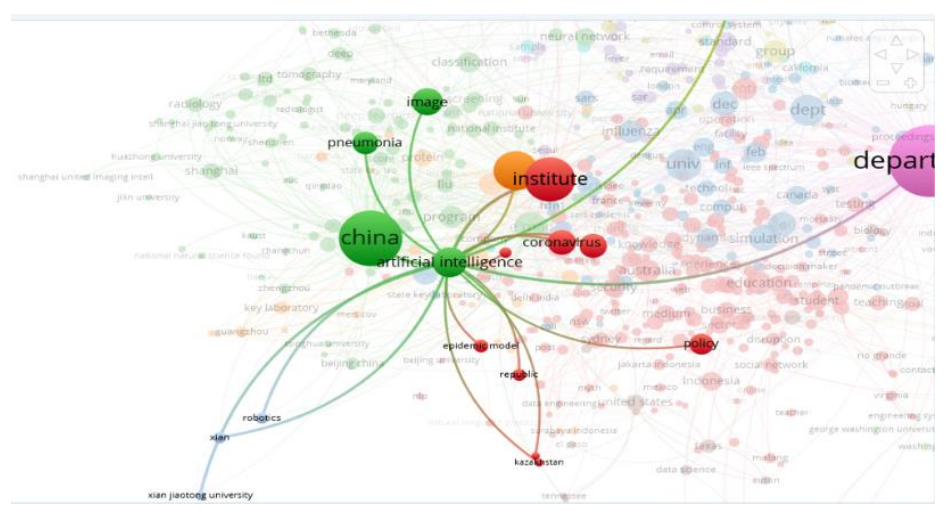

Gambar 17 Peta link topik Artificial Intelligence pada IEEExplore 


\subsection{Deep Learning}

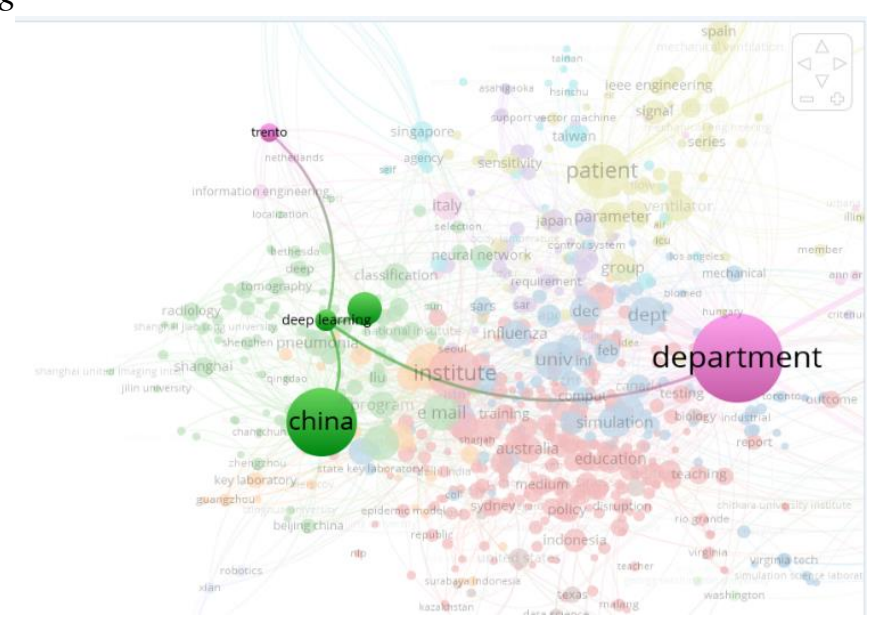

Gambar 18 Peta link topik Deep Learning pada IEEExplore

Topik Deep Learning pada gambar 18 di atas menampilkan link dengan topik China, Trento dan department.

\subsection{Internet of Thing}

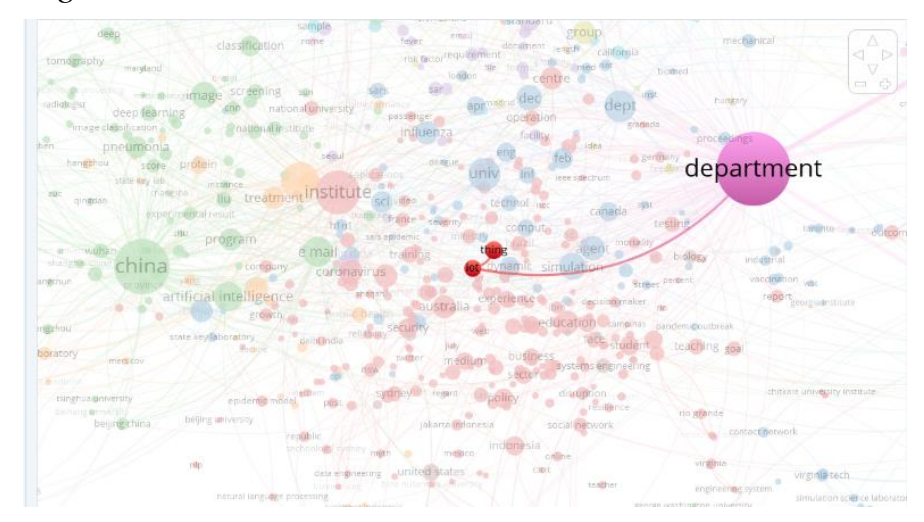

Gambar 19 Peta link topik IoT pada IEEExplore

Dari pemetaan kelima topik penelitian: Artificial Intelligence, Machine Learning, Data Mining, IoT, dan Deep Learning dari empat sumber penyedia data: Scopus, Google Scholar, IEEEXplore, dan Crossref, maka dihasilkan kesimpulan sebagai berikut:

Tabel 3 Hasil Pemetaan berdasarkan Link

\begin{tabular}{|l|c|c|c|c|c|c|c|c|}
\hline \multirow{2}{*}{ Topik } & \multicolumn{2}{|c|}{ Google Scholar } & \multicolumn{2}{|c|}{ Crossref } & \multicolumn{2}{c|}{ Scopus } & \multicolumn{2}{c|}{ IEEEXplore } \\
\cline { 2 - 9 } & Jml link & $\%$ & Jml link & $\%$ & Jml link & $\%$ & Jml link & $\%$ \\
\hline $\begin{array}{l}\text { Artificial } \\
\text { Intelligence }\end{array}$ & 19 & $51,35 \%$ & 0 & 0 & 13 & $33,33 \%$ & 16 & $72.72 \%$ \\
\hline $\begin{array}{l}\text { Machine } \\
\text { Learning }\end{array}$ & 0 & $0 \%$ & 60 & $66 \%$ & 6 & $15,38 \%$ & 0 & $0 \%$ \\
\hline Deep Learning & 18 & $48,65 \%$ & 21 & $23 \%$ & 9 & $23,08 \%$ & 4 & $18.18 \%$ \\
\hline Data Mining & 0 & $0 \%$ & 0 & $0 \%$ & 5 & $12,82 \%$ & 0 & $0 \%$ \\
\hline IoT & 0 & $0 \%$ & 10 & $11 \%$ & 6 & $15,38 \%$ & 2 & $9.1 \%$ \\
\hline Total Link & $\mathbf{3 7}$ & $\mathbf{1 0 0 \%}$ & $\mathbf{9 1}$ & $\mathbf{1 0 0 \%}$ & $\mathbf{3 9}$ & $\mathbf{1 0 0 \%}$ & $\mathbf{2 2}$ & $\mathbf{1 0 0 \%}$ \\
\hline
\end{tabular}


Dari data pada tabel 3, dihasilkan grafik seperti pada gambar 20.

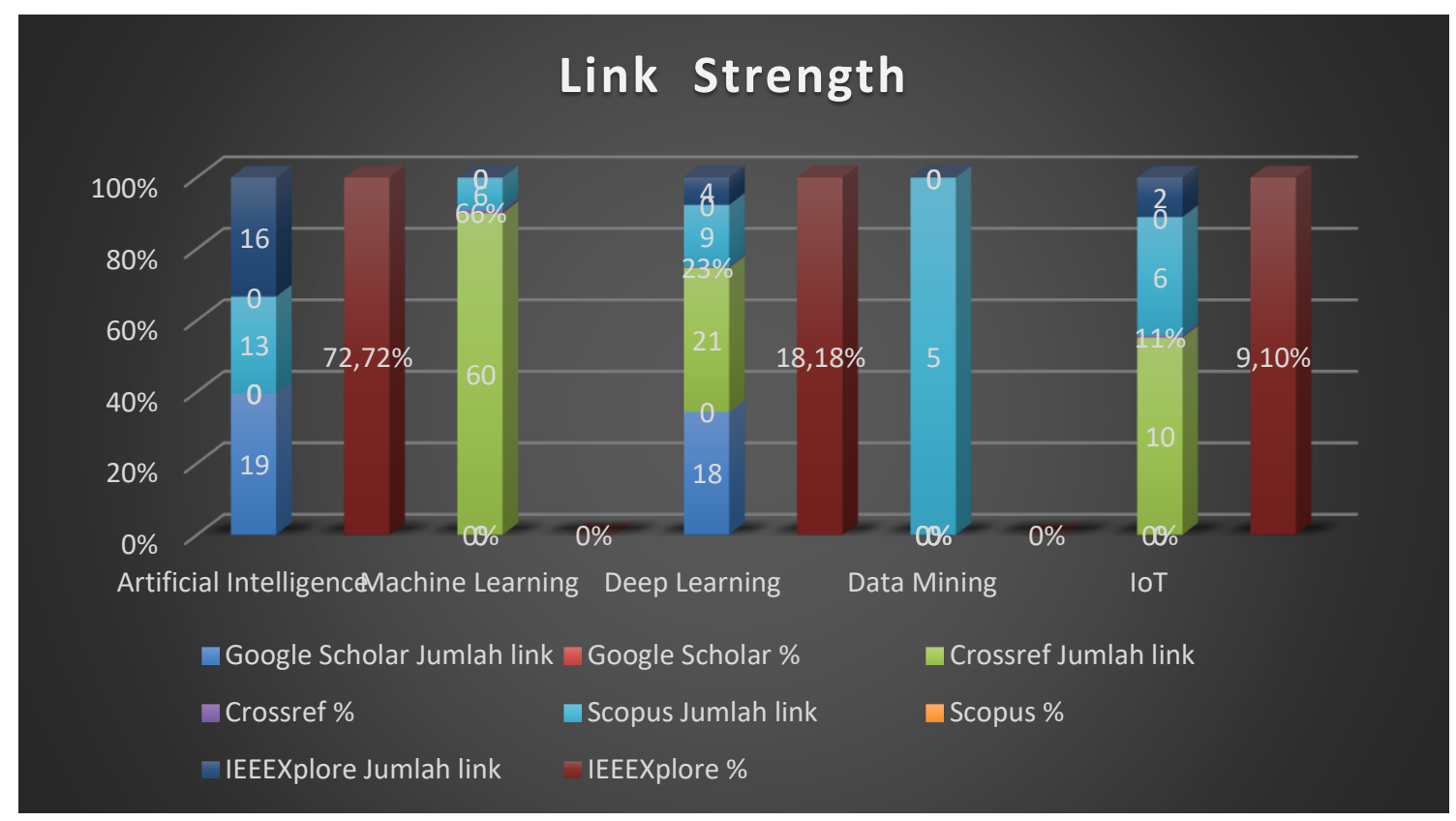

Gambar 20 Grafik Hasil Pemetaan berdasarkan Link

\section{KESIMPULAN DAN SARAN}

Analisis bibliometrik digunakan untuk menghasilkan pemetaan dari riset Covid-19 dengan topik Machine Learning, Artificial Intelligence, Deep Learning, Data Mining dan Internet of Thing selama kurun waktu satu tahun yaitu Januari hingga Desember 2020 dan dinyatakan bahwa jumlah publikasi riset pada Scopus masih sangat tinggi dibandingkan google sholar, crossref, dan IEEE Explore. Sementara visualisasi link strength menunjukkan bawa hasil riset topik Deep Learning yang paling kuat hubungannya disusul topik Artificial Intelligence, Internet of Thing, Machine Learning, dan Data Mining. Sehingga masih terdapat peluang penelitian mengenai covid 19 dari ke empat topik tersebut. Penelitian dapat dilanjutkan dengan melakukan analisis lebih lanjut terkait link strength antara topik penelitian di bidang ilmu komputer dengan bidang lainnya, khusus nya terkait dengan covid 19.

\section{DAFTAR PUSTAKA}

[1] Rothan HA, Byrareddy SN. The epidemiology and pathogenesis of coronavirus disease (COVID-19) outbreak. J Autoimmun. 2020; published online March 3. DOI: 10.1016/j.jaut.2020.102433.

[2] Ren L-L, Wang Y-M, Wu Z-Q, Xiang Z-C, Guo L, Xu T, et al. Identification of a novel coronavirus causing severe pneumonia in human: a descriptive study. Chin Med J. 2020; published online February 11. DOI: 10.1097/CM9.0000000000000722.

[3] World Health Organization. Naming the coronavirus disease (COVID-19) and the virus that causes it [Internet]. Geneva: World Health Organization; 2020 [cited 2021 January 27]. Available from: https://www.who.int/emergencies/diseases/novel-coronavirus2019/technical-guidance/naming-the-coronavirus-disease-(covid-2019)-and-the-virusthat-causes-it.

[4] Hayat Ouassou, Loubna Kharchoufa, dkk The Pathogenesis of Coronavirus Disease 2019 (COVID-19): Evaluation and Prevention July 2020 Journal of Immunology Research Vol 
2020 (New Insights into Immune-based Diagnosis, Therapy and Prophylaxis for Infectious Diseases 2020):7 DOI: 10.1155/2020/1357983

[5] World Health Organization. Global Situation WHO Coronavirus Disease (COVID-19) Dashboard [Internet]. Geneva: World Health Organization; 2021 [cited 2021 January 29]. Available from : https://covid19.who.int/

[6] Iqrak Sulhin, Covid-19, Pemenjaraan Berlebihan, Dan Potensi Katastrofe Kemanusiaan, Jurnal Hukum \& Pembangunan 50 No. 2 (2020): 400-422

[7] Nur Indah Fitriani, Tinjauan Pustaka Covid-19: Virologi, Patogenesis, Dan Manifestasi Klinis Jurnal Medika Malahayati, Volume 4, Nomor 3, Juli 2020

[8] Capobianco-uriarte M, Casado-belmonte P, Mar G, Ter E. 2019. A Bibliometric Analysis of International. doi: 10.3390/su1 1071877

[9] Indah Hartati, dkk, Analisa Bibliometrik Publikasi Ilmiah Bertema Biorefineri Biomassa Berlignoselulosa, Inovasi Teknik Kimia. Vol. 5, No.1, April 2020, Hal 42-49, ISSN $2527-$ 614X, e-ISSN 2541-5891

[10] N. J. V. Eck, Methodological Advances in Bibliometric Mapping of Science, Utrecht: Erasmus University Rotterdam, 2011.

[11] Van Eck, N. J., \& Waltman, L. (2010). Software survey: VOSviewer, a computer program for bibliometric mapping. Scientometrics, 84(2), 523-538. http://doi.org/10.1007/s11192-009-0146-3

[12] Leydesdorff, L., \& Rafols, I. 2012. Interactive Overlays: A New Method for Generating Global tbh Maps from Web-of-Science Data. Journal of Informetrics, 6, 318- 332

[13] LI Jie, GUO Xiaohong, SHEN Shifei, ALEKSANDAR Javanovic. 2014. Bibliometric Mapping of "International Symposium of Safety Science and Technology (1998-2012)".

Procedia Engineering 84, 70-79

[14] N.J.V. Eck, Waltman Ludo. 2020. Vosviewer Manual version 1.6.16, Universiteit Leiden, CWTS Meaningful metrics,

[15] Qin He. 1999.Knowledge Discovery Through Co-Word Analysis, Library Trend Vo. 48. No.1, Summer, 133-159, University of Illinois 